Subscription Information: Politics and Religion (ISSN 1755-0483) is published quarterly in March, June, September, and December by Cambridge University Press, 32 Avenue of the Americas, New York, NY 10013-2473 USA/The Edinburgh Building, Shaftesbury Road, Cambridge CB2 8RU, UK for the Religion and Politics Section of the American Political Science Association. Annual subscription rates for Volume 8 (2015): Institutional subscription rates, print and online: US \$330.00 in the USA, Canada, and Mexico; UK $£ 189.00+$ VAT elsewhere; Institutional online only: \$268.00 in the USA, Canada, and Mexico; UK $£ 150.00+$ VAT elsewhere. Institutional subscription correspondence should be sent to: Cambridge University Press, 100 Brook Hill Drive, West Nyack, NY 10994-2133, USA for customers in the USA, Canada, or Mexico. Customers elsewhere should contact: Cambridge University Press, The Edinburgh Building, Shaftesbury Road, Cambridge CB2 8RU, UK.

Editorial Office: All manuscripts must be submitted through the Editorial Manager website: www.editorialmanager.com/prj. Correspondence concerning submissions and manuscripts under review should be sent to: Paul A. Djupe, Department of Political Science, Denison University, P.O. Box 810, Granville, $\mathrm{OH}$ 43023. E-mail: politicsandreligionjournal@gmail.com or to: Angelia Wilson, Department of Political Science, The University of Manchester, Oxford Road, Manchester M13 9PL, United Kingdom. E-mail: politicsandreligionjournal@ gmail.com

Copyright (C) 2015 Religion and Politics Section of the American Political Science Association. No part of this publication may be reproduced, in any form or by any means, electronic, photocopy, or otherwise, without permission in writing from Cambridge University Press, Rights and Permissions Manager, 32 Avenue of the Americas, New York, NY 10013-2473 USA. For further information see http://us.cambridge.org/information/rights/ or http://www.cambridge.org/uk/ information/rights/.

Photocopying information for users in the USA: The Item-Fee Code for the publication (1755-0483/15 \$25.00) indicates that copying for internal or personal use beyond that permitted by Sec. 107 or 108 of the U.S. Copyright Law is authorized for users duly registered with the Copyright Clearance Center (CCC), provided that the appropriate remittance of $\$ 25.00$ per article is paid directly to CCC, 222 Rosewood Drive, Danvers, MA 01923. Specific written permission must be obtained for all other copying.

Internet Access: This journal is included in the Cambridge Journals Online service which can be found at: http://journals.cambridge.org/. For further information on other Press titles access go to: http://www.cambridge.org/.

Postmaster: Send address changes to Politics and Religion, Cambridge University Press, 100 Brook Hill Drive, West Nyack, NY 10994-2133.

Advertisement: UK: ad_sales@cambridge.org; US: USAdSales@cambridge.org 


\section{Politics and Religion}

Volume 8
Number 1

March 2015

Editors' Note

\section{ARTICLES}

The Choosing People: Interpreting the Puzzling Politics of American Jewry Kenneth D. Wald

American Religious Traditions, Orthodoxy, and Commitment in Public Opinion toward Torture

H. Whitt Kilburn and Brian J. Fogarty

Attitudes toward Mormons and Voter Behavior in the 2012 Presidential Election

George Hawley

Unlikely Friends of the Authoritarian and Atheist Ruler: Religious

Groups and Collective Contention in Rural China

Yu Tao

Catholic and Muslim Human Rights Activism in Violent Internal Conflicts Güneş Murat Tezcür

Is Islam a Cure for Ethnic Conflict? Evidence from Turkey Mehmet Gurses

"Doing God" in Number 10: British prime ministers, religion and political rhetoric

Andrew S. Crines and Kevin Theakston

FEATURED REVIEW EXCHANGE

BOOK REVIEWS

CONTRIBUTORS TO THIS ISSUE 